\title{
Prospects for Industrial and Post-Industrial Tourism in Kuzbass Coal Mining Cluster
}

\author{
Nadezda Rabkina ${ }^{1}$, Oxana Pavlova ${ }^{1}$, Olga Valko $^{1 *}$ \\ ${ }^{1}$ Kemerovo State University, 650000, 6 Krasnaya St., Kemerovo, Russia
}

\begin{abstract}
This article explores Kuzbass potential for industrial and postindustrial tourism, drawing on successful foreign experience and several Russian cases. We identified common international trends in using industrial heritage and outlined the challenges that Russian companies are facing on the way towards a post-industrial paradigm. Western industrial museums present their local industry in the global context, while showing its impact on local community and culture. They make a wide use of modern technology, establish links with science and business, support local arts, and involve authentic members of the industry. Russia, however, can boast very few examples of industrial tourism (e.g. the Krasnaya Gorka Museum in Kemerovo), which is largely seen as having a purely academic appeal. Yet, Kuzbass, with its long history of coal-mining and other industries, has very extensive prospects in this type of tourism. To prove it, we performed a SWOT analysis of a prospective tour into reclaimed lands which showed far more strengths and opportunities for integrating local community, business, and industrial heritage than weaknesses and threats.
\end{abstract}

\section{Introduction}

The western world has long moved on from the industrial to the post-industrial era. As a result, industrial complexes have acquired a status of post-industrial heritage. We can see how once great factories, hi-tech equipment, breakthrough transport solutions, industrial living quarters, anthropogenic landscapes, and other objects of this now-extinct way of life have turned into large museum complexes, succeeding industrial enterprises as the backbone of local communities. Many of such sites in Europe are now on the UNESCO list.

However, Russia still largely remains in the industrial chronotope. The idea that a factory or a mine can be an attractive tourist site is still new to most Russian travel agents and holiday-makers. Local entrepreneurs hardly see old industrial sites as part of tourism or a potential source of income. Many Russian tourists associate industrial museums with the library dust and academic boredom.

Another phenomenon common for Russia is that some regions are trying to change their profile and move away from their industrial past. For example, in the last decade, Kuzbass

\footnotetext{
*Corresponding author: olgav2001@gmail.com
} 
- a coal-mining region - has made numerous attempts to rebrand itself as an ecologically pristine ski resort and erase the collective memories of miners' strikes, cave-ins, or black snow. However, Kuzbass coal is not only about methane explosions, bankrupt mines, or angry coal miners blocking the Trans-Siberian Railway. Kuzbass coal is also associated with the one-of-its-kind Autonomous Industrial Colony "Kuzbass", ambitious projects of the pre-revolutionary Kopikuz Joint-Stock Company, heroic labour on the home front during World War II, mining folklore and community life, successful experience of mine reclamation, and other aspects of life.

Even if Kuzbass is destined to become an elite ski resort, its industrial history will always be there. One cannot escape from the past, but one can learn to respect it and draw lessons. All these stories have to be preserved for future generations. And although the current conditions are not really fit for industrial tourism, sooner or later it will acquire the popularity it deserves and possibly become a significant source of income for the whole region or many of its company towns.

Yet, Russia is slowly heading towards a post-industrial paradigm, sustainable development, green technology, and other global trends. In fact, some regions (e.g., Ural) are beginning to connect their future with industrial tourism. Therefore, we found it relevant to analyse the foreign experience of industrial and post-industrial tourism and see how it could be adjusted and adapted to the Russian context, particularly in Kuzbass, where it definitely has a future.

\section{Materials and methods}

Our study started with a hypothesis that Kuzbass - an industrially developed region with coal-mining in the core of its economy - has an enormous potential for industrial and postindustrial tourism. Prior to suggesting a number of ideas about how this type of tourism could be integrated into the local economy and community life, we studied the foreign experience, its key features and trends. We also analysed the situation in Russia and identified the main obstacles - cultural, social, and economic - on the way towards industrial tourism.

To collect information, we mainly relied on the Internet, particularly the web-sites of industrial and post-industrial museums and tourist organizations, both in Russia and abroad. We also analysed a number of industrial tours offered by local travel agents and educational centres. E-library publications were another valuable source of information on the topic.

In addition to observation of the local context, our methods of study included interpretation, hypothetico-deductive processing, and comparative analysis of historic, cultural, social, economic, and ecological data collected from the above sources. Finally, we developed a prospective tour into reclaimed lands in Kuzbass and performed a SWOT analysis to identify its strengths, weaknesses, opportunities, and threats.

\section{Results and Discussion}

\subsection{Industrial and post-industrial tourism in Russia and abroad}

\subsubsection{Definition}

Broadly speaking, industrial tourism means both industrial heritage sites and operating plants. It offers tourists new experience connected with production and technology, as well as with the epoch the site belongs to [1]. 
To be considered an object of industrial tourism, the site has to be open to the public on a regular basis [2] and be the primary purpose of visit for the so-called industrial tourist [3]. However, the term "industrial tourism" is somewhat ambiguous: whether it stands for operating enterprises or industrial heritage sites depends on the country. For example, France and the USA use it to refer to active enterprises, while Germany and Poland apply it mainly to museums. It seems sensible to use the approach adopted in Britain and refer to regular commercial tourist visits to operating enterprises as industrial tourism and visits to museums and industrial heritage sites as post-industrial tourism [4].

The term "industrial" covers all activities including primary industry, mineral production and processing, state sector and private business, profit and non-profit organizations, services, etc. [5]. Any site of tourist attraction consists of three components: people (tourists, personnel, etc.), core (the site itself or an attractive event), and information. When it comes to operating enterprises, it is compulsory that tourist activity remains secondary $[5,6]$.

Post-industrial tourism is often regarded as part of cultural tourism as tourists get acquainted with sites or events that have a certain level of high or popular culture, thus broadening their knowledge about the world [7].

\subsubsection{Foreign experience}

Great Britain, the country with a rich industrial history, leads the world in organized postindustrial tourism. Eight out of its 28 UNESCO sites are connected with industrial heritage, mostly associated with the Victorian era and the leading role of the British Empire in the world trade and economy.

In the USA, where, just like in Russia, mining remains a way of life for several states (Pennsylvania, West Virginia and others), it is treated as a precious phenomenon of community culture with its own folklore, songs, art, attitudes, and traditions. The American National Mining Association covers 55 mining museums and offers visits to operating mining sites.

The European Union, with its depleted natural resources, has an on-going project called "European Route of Industrial Heritage." Having originated in Great Britain, Germany, and the Netherlands, it now unites more than 850 industrial heritage sites in 44 countries [8].

We analysed the web-sites of 30 industrial and post-industrial tourist destinations abroad (industrial museums and other tourist organizations) and identified a large number of common features and trends. Most of them are listed below.

- Local industry in the global context. Industrial museums tend to present their local industry as part of the world history, stressing its effect on their local community and showing its place in the global chain of industrial and historic events.

- Added focus on local community. Industrial museums feature not only industrial history but also that of their local community and its way of life. They reconstruct authentic houses, build replicas of home and shop interiors, conserve or sometimes construct whole authentic-looking streets.

- Modern technology. To create an interactive environment, museums combine authentic working equipment with modern technologies (e.g. 3D displays or interactive kiosks).

- Making use of nature. Museums take advantage of the surrounding landscape to organize view points and hiking routes, as well as use prominent landscape features on their branded materials.

- Supporting local crafts. Industrial museums support local artisan production and local industries by providing space for craft fairs, art exhibitions, and workshops. In return, they 
may acquire unique souvenirs. They strive to express their unique personality through animal mascots, photo objects, interesting characters working as guides, etc.

- Internet-friendly. Virtual space is just as important as the physical environment. Museums make use of the Internet sites, social networks, YouTube videos, bar-codes, and hash tags, as well as organize creative selfie zones and online marketing campaigns.

- Authentic guides. Museums invite professional industry workers, e.g. retired miners, to work as guides. They can easily win the trust of the audience and personalize the information with true stories and professional jargon.

- Unique concept. Some unique feature or an artefact - a once-largest installation, the first-of-its-kind apparatus, or a never-before experience - can become the core of the museum's concept.

- Connecting with modern arts. Museums actively integrate modern arts related to the main concept by holding contests, organizing exhibitions and other events.

- Eco-friendly. Tour organizers try to emphasize the industry's eco-vector by showing that once hazardous production is getting less so, or that the industry is doing its best to become more environmentally friendly.

- Full infrastructure. Museums boast all necessary facilities and services, including public catering.

- Integrated character. Objects of industrial tourism tend to gather in clusters so one route might include visits to operating enterprises, closed heritage sites, related industries, museums of local lore, as well as indoor and open-air places of interest.

- Targeting families. Families are becoming a primary target audience for industrial museums so they organize special diversified programs for all ages.

- Open to partnerships. Industrial and post-industrial tourist organizations seek partners among all sorts of social groups - schools, golden age clubs, labour unions, etc.

- Linking with science. Museums contribute to the development of science by organizing field practice for students, providing venues for scientific conferences, welcoming schoolchildren on career days, employing academics to conduct historical research, etc.

- Seeking business sponsorship. Historical heritage sites seek financial support from businesses and trusts and can adjust their activities to meet their needs.

\subsubsection{Russian experience}

Although Russia is an industrial country, industrial heritage sites are more likely to be seen here as an obstacle to achieving greater production as they are often located on the premises of operating plants. As a result, there are few closed industrial enterprises with an intact core that would go back to the era of the Industrial Revolution. Quite common is a picture of ruined structures located in operating workshops or deep in the territory of a large industrial complex.

If an industrial enterprise with a long history has a museum, it is highly unlikely to be open to the public other than students or academics. Having to welcome regular tour groups is largely regarded as a nuisance because of insurance issues and lack of regulations on industrial tourism. Operating enterprises see no immediate profit in commercial industrial tourism. Neither do they look at it as an opportunity to promote the company or raise its spirit. Financial aspects remain more important than improving the image of the industry.

However, some regions are already drawing road maps of their economic development based on the prospects of industrial tourism, e.g. the Ural region with its Nizhny Tagil Plant of Steel Structures, the Steel Route at the Magnitogorsk Iron and Steel Plant, and the Chelyabinsk Pipe Rolling Plant; Saint-Petersburg with its old factories and docks; Moscow 
with its confectionary factories; small old towns of the Golden Ring Route with their traditional crafts, etc. [9].

Food industry, of all sectors, was the first to take advantage of industrial tourism as it could produce an immediate profit and marketing buzz. On the other hand, Russia has a gas and oil industry that is rich enough to care about its image. For example, the Rosneft Oil Company sponsors a route "The Black Gold of Russia" in Tyumen. The Lukoil Oil Company funded a hi-tech interactive museum of oil industry in the Komi Republic.

Kuzbass can boast only one industry-related museum that shares most of the characteristics of successful foreign tourist destinations listed above - the Krasnaya Gorka (Red Hill) Museum in Kemerovo. In fact, it is a cluster of several industrial heritage sites, including some unique examples of Dutch architecture. Located right across the river Tom', opposite the coking plant and the power station, it offers a breath-taking view of the industrial landscape.

Below is a list of features that it shares with foreign industrial museums. In particular, the Krasnaya Gorka:

- tries to preserve the local coal-mining culture;

- preserves and promotes the heritage of unique historical experiments, i.e. the Industrial Autonomous Colony "Kuzbass" that united enthusiastic socialists from all over the world for the sake of Soviet heavy industry in the 1920s;

- has accounts in all major social networks and actively uses the Internet as a marketing tool;

- hosts various cultural events, thus becoming an anchor point for the local community;

- improves the status of the once shabby coal-mining district by the sheer fact of its existence;

- conducts serious scientific research into the history of the Industrial Autonomous Colony "Kuzbass" and publishes The Krasnaya Gorka Almanac to promote local lore studies;

- exhibits in its yard some authentic mining equipment, including a huge power-shovel and a one-rail elevator;

- makes use of modern technology (e.g. interactive kiosks, a large transparent screen for presentations, a 3D excursion to the power station);

- welcomes various city events and offers its premises for meetings, workshops, and other activities;

- supports the local arts-and-crafts community by ordering souvenirs of various kinds;

- organizes photo zones, on-line contests, and other events, encouraging its visitors to enlarge its online presence;

- has a mascot called "Gamazyulya," a mythological patron of East-European coal miners, which features in souvenirs and sometimes acts as a tour guide, etc.

\subsection{Kuzbass potential for industrial and post-industrial tourism}

\subsubsection{Current situation with industrial tourism}

Siberian recreational resources are competitive advantages of this region. According to The Strategy for Developing Tourism in Kemerovo Region up to 2025, tourism is to become one of the most important growth points for such depressed regions as Altai, Buryatia, Tuva, Khakassia, and Trans-Baikal, and for such industrially developed areas as Irkutsk, Kemerovo, and Novosibirsk. And although the road map does not mention industrial tourism as such, industrial and post-industrial tourism is extremely flexible and can become part of other directions supported by the Strategy, e.g. cultural or historical tourism, business or adventure, as well as ecotourism. 
Today, Kuzbass boasts 132 officially registered manufacturing enterprises [10]; yet, its industrial and post-industrial tourism is still in its infancy. A brief analysis of tour offers on the Internet proved that local commercial industrial tourism barely exists at all. Strange as it may sound, Kuzbass - with its long mining history - does not have a single mine open to the public. Even stranger is the fact that the so-called Seven Wonders of Kuzbass include no industrial sites connected with coal mining or coal processing. However, on their official web-sites, the largest local miners (Chernigovets, Kedrovsky, Barzassky, and Bachatsky) often publish reports about organized visits to their facilities. Yet, none of these visits falls under the definition of industrial tourism.

The local coal mines and refineries welcome mining students, high-school students, miners' children (on Coal Miner's and Metallurgist's Days), honoured guests (celebrities, politicians, athletes, etc.), journalists, bloggers and the like. A group of interested individuals (e.g. being in Kuzbass on business) can ask for a visit to the Koksokhim coking plant or one of local open mines but they would have to address them directly. For example, some years ago, Koksokhim organized an exclusive excursion for the descendants of the foreign engineers who worked in the Autonomous Industrial Colony "Kuzbass" in 1921-1927. The visit was arranged by the local council and the Krasnaya Gorka. Naturally, such visits are not commercial. Koksokhim has some monuments of historical significance constructed by the Kopikuz Company in the pre-revolutionary era. For example, the reinforced-concrete building for coal preparation with its elegant arches and curved piles is one of its kind in Siberia, and some of the river-stone constructions are the oldest masonry structures in the region. Of public interest can also be some historical equipment and furnaces, let alone the impressive coke quenching process. However, coal processing is potentially dangerous, and the plant itself is an object of strategic significance. Therefore, regular public access would be associated with potential risks or red tape - the problems that would outweigh any commercial or publicity benefits. Coal mines are driven by the same concerns when they refrain from regular group visits.

A brief analysis of local tour offers revealed only one product that belongs to industrial tourism in the full sense of this term. The Meridian travel agency offers a tour called "Industrial Kuzbass" around the oldest coal-mining sites in Kuzbass, namely the Bachatsky open mine and the Bachatsky smelter (1816) in the towns of Belovo and Gurievsk. This one-day tour, including transfer and lunch, seems to be the only commercial tour offer related to coal mining.

\subsubsection{All-Russian trends in industrial tourism}

Among other sectors, food industry remains the source of most popular tour offers in Kuzbass. The abovementioned Meridian travel agency sells several tours of confectioners, farms, and breweries. Using the flexibility of industrial tourism, the agency combines visits to food enterprises with excursions to local lore museums and historical sites in several Siberian towns. Such one-day trips are advertised as family events. This way, local industrial tourism follows an all-Russian trend, i.e., food companies make a good use of organized tours since it brings them immediate profits. Naturally, such marketing buzz is effective for small and medium-sized food producers, rather than mining and heavy industry enterprises.

Another all-Russian trend that we can observe in the local industrial tourism is its connection with educational tourism. The Kemerovo Regional Centre for Children and Youth Tourism offers a number of industrial tours for school children, e.g. to the Kemerovo radio station and TV centre, meteorological and hydrometeorological stations, fire units, the airport, the backstage of the Drama Theatre, and other places of interest. 
Finally, the third trend relates to culture and service sectors and is fuelled by local enthusiasts. For instance, members of the "Inside and Outside" social project organize cheap excursions to the hi-tech office of a local Internet provider, flower shops, a printing firm, an embroidery workshop, a brewery, the oldest department store in Kemerovo, the Puppet Theatre, etc. Unfortunately, such excursions are irregular and the initial enthusiasm seems to fade away as these scarce visits fail to bring the instant profit the hosts might have expected.

\subsubsection{Obstacles for post-industrial tourism}

The situation with post-industrial tourism is becoming critical in the context of on-going deterioration of old Soviet and pre-revolutionary industrial buildings. The museumification of potential industrial heritage is a good option when it includes the whole production complex. Naturally, it is easier to plan a conservation of an old workshop than to restore a partially ruined building [11].

In the early 2000s, the Krasnaya Gorka considered turning one of the old river-side shafts into a museum and asked several local coal miners to estimate a possibility of restoring at least some meters of the currently closed mine throats. The miners were quite categorical: no coal enterprise would risk its people to restore a possibly gassy mine with rotten beams, unreliable planning documentation, and coal fire hazards. Eventually, the museum modelled some elements of underground mining on the ground floor of its main building. Currently, the river-side shafts are sealed, but you can see the blocked throats during an excursion to Gorelaya Gora (Smoking Hill) - a natural site where coal was discovered in 1721. Unfortunately, the route is seasonal and too challenging for tourists with special needs.

As for local specialized museums, they attract experts, but not the general public. For example, Kemerovo has a unique museum of coal at the Institute of Coal and Coal Chemistry (Siberian Branch, Russian Academy of Sciences). However, the museum has a clear scientific and career-building orientation. There is no information about the tickets or working hours on its web-site, which clearly indicates its non-profit character [12].

Modern mass tourism borders on entertainment. However, all local attempts to marry post-industrial tourism with entertainment have remained on paper due to their uneconomic character. Some years ago, Kemerovo had an ambitious idea to restore the cable road that used to transport coal from the steep right bank of the Tom' river to the coking plant and the power station on its flat left bank. Its implementation could have given the necessary "zest" to the concept of post-industrial tourism and possibly been more profitable than many other tourism development projects. However, it would have required unprecedented funding. Another example is the utopian project "City of the Sun" initiated by a "group of enthusiastic citizens" [13]. Their ambitious project involved converting some old houses designed by the Dutch architect J. van Loghem into an art space. What they did not take into account was the isolation of the houses from the city centre, as well as enormous costs and poor infrastructure, let alone the unwillingness of the city council to undertake a commercially unfeasible project.

\subsubsection{Prospects for local industrial and post-industrial tourism}

Having analysed some of the existing projects in Russia and abroad, we can identify the following prospects for local industrial and post-industrial tourism in Kuzbass.

Firstly, 3D excursions could offer a good alternative to visiting potentially dangerous or sensitive sites. The Krasnaya Gorka has recently introduced a virtual tour of the Kemerovo Power Station. The project was funded by the Siberian Generating Company. Just as 
spectacular, so it seems, might be a 3D underground tour around a coal mine or a virtual flight over an open pit.

Secondly, the future of local industrial tourism may lie in the improvement of the existing tourist routes. For example, the Krasnaya Gorka organizes seasonal two-hour trips to the foot of Smoking Hill, where the first local coal deposit was discovered back in 1721 . Tourists can see an impressive stone jetty, an industrial landscape, the remains of the cable road, and the closed entries to the mines. Unfortunately, the route is accessible only from August to October due to seasonal shifts of the river level and the poor quality of the path. However, a dam and some basic renovation could solve the problem. The embankment line between the bridge and the jetty could be made tourist-friendly and equipped with magnifying viewers to observe the coking plant and the power station across the river.

Thirdly, industrial tourism could be used to preserve the local mining culture and lifestyle. It would be a good idea to purchase one of J. van Loghem's houses and turn it into an exhibition of the mining community life back in the 1920s.

Fourthly, the focus of industrial tourism could be shifted onto a coal-mining landscape, which is often associated with ecology. The industrial landscape was formed at the industrial stage of social development as a result of scientific and technological achievements and engineering solutions. It reflects the whole complex of those processes and phenomena that can be called industrial culture [14]. One can be awed by colossal mine dumps from a special viewing platform at the Kedrovskaya open mine or from the highway, as the area of the mine is closed to the public. However, the industrial landscape is not only open mines and on-going excavations but also reclaimed sites. Local depleted open mines are planted with pines and buckthorn bushes, showing a good example of sustainable mining development. Since land reclamation in Kuzbass goes back quite a long way, some of the reclaimed areas have turned into real forests called "posadki" ("planted plants"). Most of these new forests are easily accessible by car on old industrial roads, so people go there to gather mushrooms and berries or have picnics. For example, it would seem quite a good idea to create a tourist product based on the reclaimed land around the closed Vladimirskaya mine (the former Volkov mine). It is a 50 -minute bus ride from the city centre, and some of the reclaimed areas are over 60 years old. Historically, they formed a unique landscape of old open pits and dumps covered with pine trees and buckthorn bushes that gradually merged with authentic black taiga. The border between the real Siberian taiga and the "artificial" pine forest is practically invisible.

Finally, industrial tourism could be mixed with almost any other type of tourism. For instance, its cultural and educational version could tell a story of local industry and tourist culture in the USSR, the oeuvre of Kuzbass poets and bards, local taiga flora and fauna, etc. Married with sports and fitness tourism, it could feature Nordic walking, skiing, snowmobiling, orienteering, yoga, "tree-hugging", and other activities. Combined with entertainment or adventure tourism, the route could be modified as a quest. Also, industrial tourism can be adjusted to ecotourism and involve collecting garbage, studying land reclamation techniques, and other environmental efforts. A picnic with coal miner's food or picking mushrooms and berries can easily shift the paradigm into the sphere of gastrotourism.

In view of the above, we designed a prospective tour into reclaimed lands and performed its SWOT analysis (Table 1). 
Table 1. SWOT analysis of a tour into reclaimed lands.

\begin{tabular}{|c|c|}
\hline $\begin{array}{l}\text { Strengths: } \\
\text { - unique landscape: a mixture of planted } \\
\text { pine forest and authentic taiga; } \\
\text { - possibility of skiing in winter (integration } \\
\text { into fitness tourism); } \\
\text { - close location: an hour's drive from the } \\
\text { city centre; } \\
\text { - easy access by public transport; } \\
\text { - drive through historical places: the road } \\
\text { runs through the Miners Avenue, the most } \\
\text { actively developing historical part of the } \\
\text { city; } \\
\text { - flexible transport: various well-trodden } \\
\text { paths and old roads are available for both } \\
\text { SUVs and bicycles; } \\
\text { - possibility of hunting: several hunting huts } \\
\text { have been popular among tourists since the } \\
\text { 1970s; } \\
\text { - mining culture: nearby are some mining } \\
\text { buildings, a chapel with bells made from } \\
\text { gas cylinders, a small river with a bridge, } \\
\text { etc. }\end{array}$ & $\begin{array}{l}\text { Weaknesses: } \\
\text { - seasonal character: the route can be } \\
\text { challenged by mud, tall grass, gnats, or } \\
\text { tics from March to August and in } \\
\text { November; } \\
\text { - no access for disabled people: the route } \\
\text { is not accessible for tourists with special } \\
\text { needs. }\end{array}$ \\
\hline $\begin{array}{l}\text { Opportunities: } \\
\text { - trigger for developing old mining districts; } \\
\text { - restoring the good name of the industry, if } \\
\text { successful; } \\
\text { - flexible timing: from several hours to a } \\
\text { weekend with an overnight stay in a } \\
\text { camping site; } \\
\text { - easy diversification according to the type } \\
\text { of tourism, purpose, and target audience; } \\
\text { - flexibility and easy integration into some } \\
\text { other excursion; } \\
\text { - benefits for local residents: former miners, } \\
\text { foresters, and local farmers can work as } \\
\text { guides or provide other services; } \\
\text { - trigger for developing camping: local } \\
\text { forestry managers can create good camping } \\
\text { sites; } \\
\text { - possibility of funding from mining } \\
\text { enterprises. }\end{array}$ & $\begin{array}{l}\text { Threats: } \\
\text { - old industrial remnants: a possible } \\
\text { presence of unmarked shaft entrances, } \\
\text { pipes sticking out of the ground, etc.; } \\
\text { - lack of enthusiasm from Kemerovo } \\
\text { residents (main target audience) who can } \\
\text { visit these places for free by bus or car } \\
\text { and are not ready to perceive their } \\
\text { customary landscape as something unique } \\
\text { or bearing historical and cultural } \\
\text { significance; } \\
- \text { potentially dangerous wildlife, e.g. } \\
\text { bears, elks on heat, hives of wild bees, } \\
\text { etc. }\end{array}$ \\
\hline
\end{tabular}

As we can see, the strengths and opportunities of our prospective tour far outweigh its weaknesses and threats. Most importantly, such tours can promote partnerships between former and current coal miners, local residents, travel agents and other businesses, environmentalists, historians, volunteers, and other members of our regional community. They can present Kuzbass as a coal-mining region that cares about its people and environment, strives to preserve its local history and culture, takes pride in its core industry, promotes sustainable development, and is in touch with modern global trends in industrial and post-industrial tourism. 


\section{Summary}

Although Russian industrial and post-industrial tourism is still in its infancy, regions such as Kuzbass are making the first steps in this direction to preserve their industrial heritage a vital part of their local culture - for future generations. A good example is the Krasnaya Gorka Museum in Kemerovo that shares most of its features with successful foreign museums of such kind. Despite current challenges and obstacles of economic, social, and cultural nature, industrial and post-industrial tourism is bound to acquire a wider tourist appeal in Kuzbass. Its prospects include virtual tours to potentially dangerous or sensitive industrial sites, seasonal routes to old remnants of industrial heritage, reconstructions of historical architecture, exhibitions of mining community life, trips to reclaimed lands, and products integrated with education, sports, entertainment, and other types of tourism.

\section{References}

1. V. Sorochan, Global and National Problems of Economics, 2, 60-61 (2014)

2. W.J. Bregman, Industrial tourism visits: the role of company tours within companies' strategies. Case study of companies organizing company tours in the Amsterdam metropolitan region. (Master Thesis, Erasmus University Rotterdam, 2011)

3. F. Evenepoel, Analyse van het industrieel toerisme in België. Gevalstudie. De Open Bedrijvendagen (Eindverhandeling, Universiteit Hasselt, Zakenwezen, 2006)

4. A. H. J. Otgaar, Industrial Tourism, Where the Public Meets the Private (ERIM PhD, Series in Research in Management, 2010)

5. E.A. Frew, Industrial Tourism: A Conceptual and Empirical Analysis (Victoria University, Victoria, 2000)

6. I. Kelly, W. Dixon, Journal of Tourism Studies, 2:1, 21-28 (1991)

7. H. Richards, Cultural Tourism. Global and Local Perspective (Howart, London, 2007)

8. Z. Kruczek, M. Kruczek, Pol. J. Environ. Stud., 25:2, 895-902 (2016)

9. Rosturism, Ural is heading towards industrial tourism (UFU, Ekaterinburg, 2010)

10. Fabrikators-2019. URL: https://fabricators.ru/zavody/kemerovskaya-oblast

11. S. Spitsin, Expert Siberia, 46, 432, (2014)

12. Coal Museum-2020. URL: http://museum.icc.kemsc.ru/default.html

13. Here will be the City of the Sun (Kuzbass Newspaper, Kemerovo, 2017)

14. O. G. Yavorskaya, Geography and geoecology in the service of science and innovative education (V.P. Astafyev Krasnoyarsk State Pedagogical University, Krasnoyarsk, 2014) 